\title{
MIEJSCE BIBLIOTEK W ERZE TRANSFORMACJI PRASY
}

\begin{abstract}
Journals of high, medium and low input consist significant part of library collection. They play also an important role in formation of society's culture. Press is not the basic source of knowledge and information, but as Polish Studies on Reading (PSR) indicates, for majority of readers, it the most valuable resource of content. Values such as professionalism, honesty, authority, reliability and intelligence are associated with the image of press. For many readers digital version of press becomes more attractive form of expression. More and more titles that traditionally were issued in paper form, now are digitalized. Report from PSR studies shows growth of interest in reading digital press. At the same time these studies show that their range of influence should grow. Report about diagnosis of reader's behaviors in relation to press does not show optimist vision for sharing press in libraries. However, both analyst's and librarians' observations of publishing market give hope that for many years to come printed press will source of knowledge and social opinion. Libraries also have the ability to offer digital press that readers find interesting.
\end{abstract}

Slowa kluczowe: prasa drukowana, prasa cyfrowa, transformacja prasy, udostępnianie prasy.

\section{Wstęp}

Funkcjonowanie bibliotek związane jest $\mathrm{z}$ trendami na rynku wydawniczym książek i prasy. Prasa należy do najstarszych środków masowego przekazu. Znaczną część zbiorów bibliotek stanowią czasopisma wysoko-, średnioi niskonakładowe, które pełnią ważną rolę w zakresie kształtowania kultury społeczeństwa. Obserwując czytelnictwo prasy, wyraźnie widzimy jego spadek, pomimo że rośnie liczba tytułów periodyków. Zdajemy sobie sprawę, że w bibliotekach udostępniane są przede wszystkim formy drukowane, a czytelnicy mając dostęp do wersji cyfrowej nie przychodzą do bibliotecznego budynku, aby skorzystać ze zbiorów. Przeniesieniu na nośniki cyfrowe podlega coraz więcej tytułów wydawanych do tej pory w wersji tradycyjnej. Z Diagnozy spotecznych zachowań czytelniczych $w$ obrębie prasy drukowanej $i$ cyfrowej 
i wyników badań zamieszczonych w raporcie z badania zrealizowanego na zlecenie Izby Wydawców Prasy opracowanego przez Millward Brown ${ }^{1}$ wynika, że transformacja prasy na nośniki cyfrowe nie musi prowadzić do pojawienia się chmur nad bytem bibliotek.

Celem artykułu jest analiza tendencji w zakresie czytelnictwa prasy, określenie kierunku transformacji prasy oraz przedstawienie perspektyw dla bibliotek.

\section{Prasa - znaczenie ustawowe, naukowe i potoczne}

W potocznym rozumieniu prasą nazywane są media drukowane, przede wszystkim dzienniki i gazety (prasa codzienna o treści ogólnej) oraz tygodniki (czasopisma) o treści ogólnej. Podobne wyjaśnienie omawianej kategorii odnajdziemy w Stowniku terminologii medialnej: „prasa - periodyki realizujące bez istotnych ograniczeń kryterium aktualności i uniwersalności treści, w praktyce nieokreślające adresu odbiorcy, realizujące cele informacji ogólnej - o wydarzeniach aktualnych, interesujących możliwie najszerszy ogół publiczności"2.

Według obowiązującej ustawy Prawo prasowe z 1984 r. prasa to: „publikacje periodyczne, które nie tworzą zamkniętej, jednorodnej całości, ukazujące się nie rzadziej niż raz do roku, opatrzone stałym tytułem albo nazwą, numerem bieżącym i datą, a w szczególności: dzienniki i czasopisma, serwisy agencyjne, stałe przekazy teleksowe, biuletyny, programy radiowe i telewizyjne oraz kroniki filmowe; prasą są także wszelkie istniejące i powstające w wyniku postępu technicznego środki masowego przekazywania, w tym także rozgłośnie oraz tele - i radiowęzły zakładowe, upowszechniające publikacje periodyczne za pomocą druku, wizji, fonii lub innej techniki rozpowszechniania; prasa obejmuje również zespoły ludzi i poszczególne osoby zajmujące się działalnością dziennikarską"3. Z powyższej definicji wynika, że pojęcie prasy dotyczy mediów, które nie tylko mają określony przedmiot działalności. Prasa, to także instytucje oraz osoby, które realizują cel, jakim jest rozpowszechnianie informacji.

\footnotetext{
${ }^{1}$ Diagnoza spolecznych zachowań czytelniczych $w$ obrębie prasy drukowanej $i$ cyfrowej. Nowe platformy dostęu do treści. Transformacja prasy. Raport $\mathrm{z}$ badania zrealizowanego na zlecenie Izby Wydawców Prasy opracowany przez Millward Brown, http://www.pik.org.pl/ upload/files/Raport\%20RYNEK\%2011-02-2014\%20\%28R\%29\%20word\%20IWP-1.pdf, [dostęp: 30.05.2017].

${ }^{2}$ Stownik terminologii medialnej, red. W. Pisarek, Kraków 2006, s. 154.

${ }^{3}$ Prawo prasowe. Ustawa z dnia 26 stycznia 1984 r., „Dziennik Ustaw” 1984, nr 5, poz. 24 , art. 7.1 .
} 
Prasa stanowi jedno z mediów masowych, co oznacza, że jej cechą jest istnienie masowego charakteru przekazu oraz posiadanie statusu podmiotu, który musi być odpowiedzialny za rozpowszechnianą treść. Media, które nie przypisują sobie odpowiedzialności redakcyjnej za rozpowszechniane treści nie mogą być zaliczone do mediów masowych, ale przede wszystkim nie mogą mieć statusu prasy. Istotnymi cechami prasy są: periodyczność, roczny interwał ukazywania się, posiadanie numeru bieżącego, otwartość, różnorodność, stałość tytułu lub nazwy, publiczne rozpowszechnianie, aktualność i wszechstronność treści, szeroki zakres przekazywania informacji, a także bezpośrednie przystosowanie do trwałego przechowywania pojedynczych egzemplarzy ${ }^{4}$.

\section{Rola prasy i jej klasyfikacja}

Współczesne media mają charakter otwarty i uniwersalny. Dawniej traktowane były jako narzędzie komunikacji w społeczeństwie, przede wszystkim na płaszczyźnie przebiegającej między elitami władzy a opinią publiczną. Niegdyś ich rola ograniczała się do odzwierciedlenia woli i interesów różnych grup oraz struktur społecznych. W tradycyjnych, zamkniętych społeczeństwach media pozostawały pod kontrolą elit władzy i kreowały opinię publiczną, dzięki całkowitej kontroli dostępu do mediów. Obecnie władza posiada ograniczone możliwości kontrolowania mediów ze względu na ich globalny zasięg oraz szybkość, z jaką przekazują informacje. Cechą charakterystyczną współczesnych mediów jest zdolność do natychmiastowej reakcji, prezentacji faktów w czasie rzeczywistym, pozostawania ze sobą w nieustannej interakcji, docierania praktycznie bez ograniczeń do wszystkich poziomów organizacji społeczeństwa ${ }^{5}$. Media stwarzają odbiorcom możliwość partycypacji i aktywnego uczestnictwa w tworzeniu kultury, dzięki interaktywności pozwalającej na włączenie odbiorcy w kształtowanie treści, ale też doboru źródeł ${ }^{6}$.

Prasa, podobnie jak inne media masowe, pełni szereg istotnych funkcji. Jej rolą i zadaniem jest periodyczne rozpowszechnianie informacji, czyli cykliczne informowanie opinii publicznej o wydarzeniach społecznych, ekonomicznych, oświatowych, kulturalnych, gospodarczych, politycznych, z zakresu muzyki, filmu i sztuki, i temu podobnych. Ze względu na podmiotową odpowiedzialność prasy informacje te przekazywane są pod określonym tytułem,

${ }^{4}$ J. Taczkowska, Zawód dziennikarza w Polsce. Między misja a postannictwem, Bydgoszcz 2012, s. 22.

${ }^{5}$ S. Jędrzejewski, Media a zmiana społeczna, [w:] Kultura, media, społeczeństwo, red. D. Wadowski, Lublin 2007, s. 263.

${ }^{6}$ P.P. Ziarek, Kultura popularna a nowe media, [w:] Konteksty kultury popularnej: pteć, sztuka, media, red. M. Jeziński [et al.], Toruń 2010, s. 199-200. 
nazwą, adresem oraz internetowym linkiem. W ten sposób redakcja bądź wydawca precyzuje cel, jaki realizuje. Periodyki internetowe, by mogły być uznane za wydawnictwa prasowe, wcale nie muszą mieć postaci typowych gazet elektronicznych, których wydawcami są tylko wielkie koncerny prasowe, firmujące jedynie znane tytuły publikatorów w systemie online ${ }^{7}$.

Czytelnicy uczestniczący w badaniu przeprowadzonym na zlecenie Izby Wydawców Prasy ${ }^{8}$ podkreślali kulturotwórczą rolę prasy, czyli wpływanie na formowanie i rozwój zainteresowań czytelników. Uważali, że prasa stanowi wartościowy zasób informacji, które cenione są za ich profesjonalizm, wiarygodność i inteligencję. Prasa porządkuje zasób informacji czytelników i zapewnia orientację w tym, co jest ważne i co stanowi przedmiot dyskursu społecznego. Ponadto informując, podnosi rangę opisywanych wydarzeń. Funkcje prasy sprowadzają się do zaspokojenia potrzeb informacyjnych z określonych dziedzin oraz potrzeb emocjonalnych poprzez zapewnienie relaksu, oderwanie się od codzienności w trakcie obcowania z lżejszymi treściami.

Ze względu na pełnione funkcje prasa dzielona jest na gazety (prasa ogólnokrajowa i lokalna) oraz czasopisma. Celem gazet jest rozpowszechnianie aktualnych, interesujących możliwie najszerszy ogół publiczności informacji. Celem czasopism jest komentowanie informacji wcześniej rozpowszechnionych. Czasopisma treści ogólnej jedynie częściowo realizują kryterium aktualności, najczęściej poprzez poszerzenie zakresu periodyczności i uniwersalności treści. Czasopisma o treści specjalnej są zróżnicowane pod względem tematu i kręgu odbiorców ${ }^{9}$.

Współczesny czytelnik posiada szeroki dostęp do prasy w wersji drukowanej, w wersji cyfrowej oraz do internetowych serwisów tytułów prasowych. Nie jest do końca sprecyzowane pojęcie prasy cyfrowej, w obrębie którego wymieniane są:

- $\quad$ gazety i czasopisma istniejące wyłącznie w postaci elektronicznej bezpłatne i płatne;

- $\quad$ specjalnie przygotowane i rozpowszechniane online wydania gazet i czasopism, przede wszystkim istniejące również na papierze;

- $\quad$ czasopisma udostępniane odpłatnie w wersji identycznej z papierową.

Z badań przeprowadzonych przez Izbę Wydawców Prasy wynikało, że czytelnicy $\mathrm{w}$ formie drukowanej poszukują informacji lokalnych, mniej

\footnotetext{
${ }^{7}$ J. Taczkowska, op. cit., s. 23-24.

${ }^{8}$ Diagnoza spolecznych zachowań czytelniczych..., [dostęp: 30.05.2017].

${ }^{9}$ Stownik terminologii..., s. 154.
} 
obszernych i dających relaks, natomiast w prasie cyfrowej poszukują dłuższych i obszernych tekstów, reportaży, wywiadów, informacji kulturalnych i innych ${ }^{10}$.

\section{Kierunek transformacji prasy (czasopism specjalistycznych, gazet codziennych, czasopism opinii, czasopism tematycznych)}

W kulturogennym oddziaływaniu prasy na odbiorców ważne jest, aby przekazywane treści miały odpowiednią jakość. Tytuły prasowe o dużym autorytecie i pozytywnym odbiorze budują swoją tożsamość w obrębie nowego dynamicznego i aktualnego narzędzia, jakim jest Internet. W opinii czytelników uczestniczących w badaniu Izby Wydawców Prasy, prasa nie jest jedynym źródłem wiedzy, ale 52,7\% badanych uważało, że stanowi najbardziej wartościowy zasób treści, a 69\% ankietowanych, że pozwala zapoznać się $\mathrm{z}$ opiniami różnych środowisk. Bezpłatne źródła informacji na portalach internetowych nie są tak dobrze oceniane. $Z$ analizy przedstawionej $\mathrm{w}$ raporcie wynika, że w porównaniu z bezpłatnymi źródłami, płatna prasa ma wśród czytelników dużo lepszy wizerunek. Jednak zakup prasy w wersji cyfrowej nie jest powszechny. Na rys. 1 przedstawiono dane dotyczące zakupu prasy w wersji cyfrowej i papierowej według Diagnozy społecznych zachowań

\begin{tabular}{|c|c|c|}
\hline \multicolumn{3}{|c|}{$\mathrm{N}=1006$} \\
\hline Tak, kupilem(am) prenumeratę czasopisma tematycznego & $4,00 \%$ & \\
\hline Tak, kupilem(am) prenumeratę gazety codziennej & 3,80\% & \\
\hline Tak, kupHem(am) prenumeratę tygodnika opinii & $2,50 \%$ & \\
\hline Tak, kupilem(am) prenumeratę czasopisma kobiecego & $2,10 \%$ & \\
\hline Tak, kupilem\{am\} wybrane wydania tygodnika opinii & $1,50 \%$ & \\
\hline Tak, kupilem(am) wybrane wydania czasopisma... & $1,00 \%$ & \\
\hline Tak, kupilem \{am) wybrane wydania gazety codziennej & $0,90 \%$ & \\
\hline Tak, kupilem(am) wybrane wydania czasopisma kobiecego & $0,70 \%$ & \\
\hline Tak, kupilem(am) dostęp do pakietu tytulów prasowych & $0,20 \%$ & \\
\hline Nigdy nie kupitem(am) & & $90,20 \%$ \\
\hline
\end{tabular}

Rys. 1. Zakup prasy w wersji papierowej i cyfrowej uczestników badania Izby Wydawców Prasy

Źródło: opracowanie własne na podstawie Diagnoza społecznych zachowań czytelniczych w obrębie prasy drukowanej i cyfrowej. Nowe platformy dostępu do treści. Transformacja prasy. Raport z badania zrealizowanego na zlecenie Izby Wydawców Prasy opracowany przez Millward Brown, http://www.pik.org.pl/upload/files/Raport\%20RYNEK\%2011-02-2014\%20\% 28R\%29\%20word\%20IWP-1.pdf, [dostęp: 30.05.2017].

\footnotetext{
${ }^{10}$ Diagnoza społecznych zachowań czytelniczych..., [dostęp: 30.05.2017].
} 
czytelniczych $w$ obrębie prasy drukowanej $i$ cyfrowej zawartych $\mathrm{w}$ raporcie z badania zrealizowanego na zlecenie Izby Wydawców Prasy opracowanego przez Millward Brown.

$\mathrm{Z}$ badań wykonanych na zlecenie Izby Wydawców prasy wynikało, że tylko 9,8\% respondentów dokonało zakupu prasy w wersji cyfrowej, w tym najczęściej wybierano prenumeratę czasopisma tematycznego, gazety codziennej, tygodnika opinii i czasopisma kobiecego. Do tych samych rodzajów prasy wykupywano dostęp do wybranych artykułów. Aż 90,2\% ankietowanych nigdy nie zakupiło dostępu do wersji cyfrowej prasy ${ }^{11}$.

$\mathrm{W}$ omawianym badaniu pytano też o przyczyny zakupu prasy w wersji papierowej. Dane dotyczące zalet wersji papierowej prasy przedstawiono na rys. 2 .

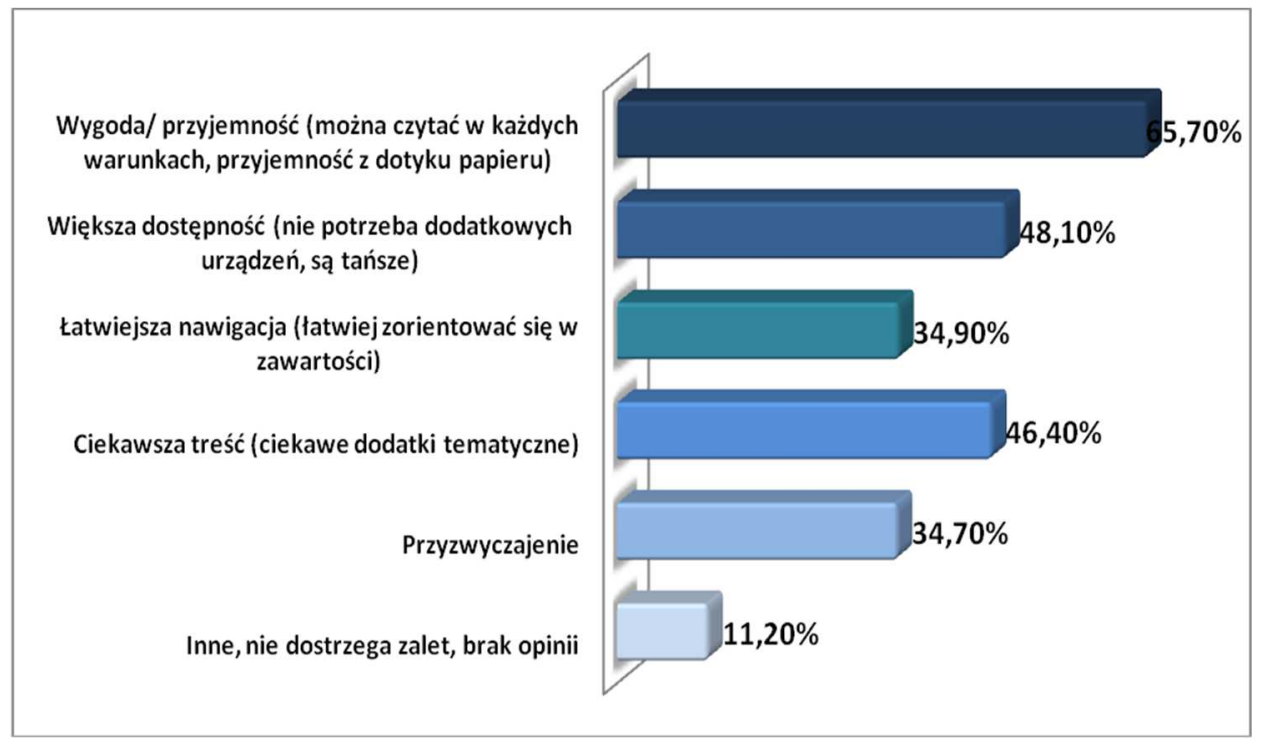

Rys. 2. Zalety prasy w wersji papierowej w opinii uczestników badania Izby Wydawców Prasy czych...

Źródło: opracowanie własne na podstawie Diagnoza spolecznych zachowań czytelni-

Czytelnicy uczestniczący $\mathrm{w}$ badaniu uzasadniali wybór prasy w wersji papierowej takimi zaletami, jak wygoda i przyjemność, w tym możliwość czytania w każdych warunkach oraz przyjemność z dotyku papieru. Cenili również większą dostępność wersji papierowej (nie potrzeba dodatkowych urządzeń, są

\footnotetext{
${ }^{11}$ Ibidem, [dostęp: 30.05.2017].
} 
tańsze). Wielu uważało, że czytając wersję papierową mają łatwiejszą nawigację (łatwiej zorientować się w zawartości), a treść jest ciekawsza (ciekawe dodatki tematyczne). Stosunkowo duża grupa respondentów $-34,7 \%$ sięgała po wersję papierową z przyzwyczajenia ${ }^{12}$.

$\mathrm{Z}$ raportu wynikało, że 17,5\% uczestników badania określiło jako prawdopodobny zakup prasy w wersji cyfrowej w ciągu najbliższych 12 miesięcy. Dane dotyczące powodów prawdopodobnego zakupu prasy w wersji cyfrowej przez 176 osób przedstawiono na rys. 3 .

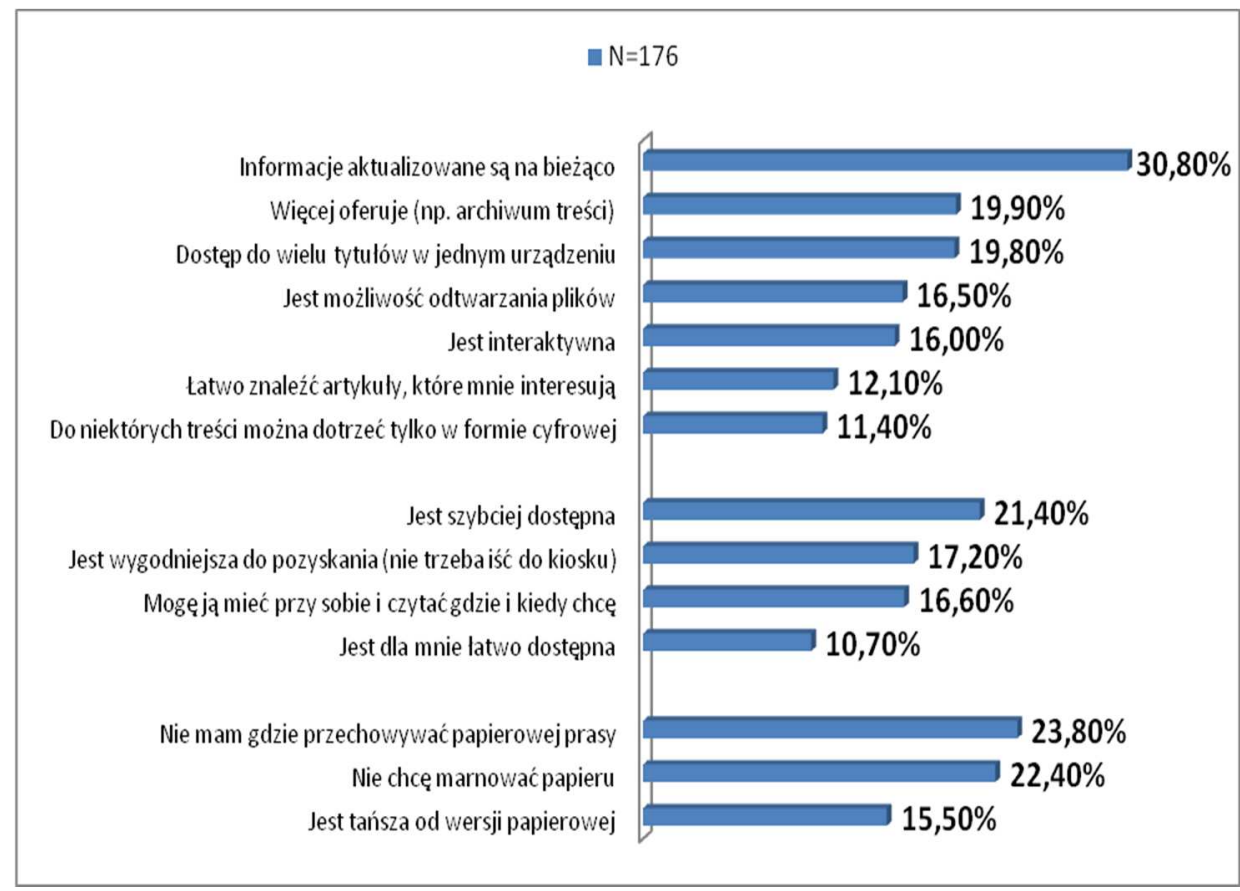

Rys. 3. Powody prawdopodobnego zakupu prasy w wersji cyfrowej w opinii uczestników badania Izby Wydawców Prasy niczych...

Źródło: opracowanie własne na podstawie Diagnoza spotecznych zachowań czytel-

Wśród powodów zainteresowania prasą cyfrową dominują te związane z ukierunkowanym, łatwiejszym dostępem do szerszego zakresu treści lepszej jakości. Wzrost zainteresowania wersją cyfrową wynikał z dostrzeżenia wielu zalet tej formy prasy. Uważano, że w prasie cyfrowej: informacje aktualizowane są na bieżąco, prasa ta więcej oferuje (na przykład archiwum treści), zapewnia dostęp do wielu tytułów w jednym urządzeniu, jest możliwość odtwarzania

\footnotetext{
${ }^{12}$ Ibidem, [dostęp: 30.05.2017].
} 
plików, łatwiej znaleźć artykuły, jest wygodniejsza do pozyskania, jest łatwiej dostępna i łatwiej ją przechowywać, niż wersję papierowa. O chęci zakupu decydowały również względy ekologiczne.

Jako powody braku zainteresowania prasą cyfrową wymieniano głównie techniczne ograniczenia i niechęć do czytania z ekranu. Sporadycznie wskazywano powody odnoszące się bezpośrednio do treści, która w Internecie mogłaby ustępować jakością, tej dostępnej w prasie drukowanej. Odnośnie treści dostępnych w Internecie panowało przekonanie, że powinny być dostępne bezpłatnie $^{13}$.

\section{Transformacja czasopism naukowych}

W bibliotece naukowej szczególnie istotne jest gromadzenie, opracowanie i udostępnianie czasopism naukowych. Czasopisma naukowe, to rodzaj czasopisma prezentującego publikacje naukowe. Na świecie wydawanych około 54 tys. tytułów czasopism naukowych, w przybliżeniu zamieszczających milion artykułów rocznie. Każdy tytuł należy do ściśle zdefiniowanego zakresu tematycznego. Publikowane artykuły mieszczące się w danym zakresie podlegają długotrwałej recenzji naukowej. W skład rady redakcyjnej wchodzą naukowcy z określonej dziedziny, którzy nadzorują proces recenzowania oraz przyjęcia lub odrzucenia nadsyłanego artykułu. Autorzy artykułów zwykle nie otrzymują gratyfikacji pieniężnych, a motywem publikowania jest wykazanie swojej działalności naukowej, która oceniana jest na podstawie liczby oraz jakości publikacji. Jedynie autorzy artykułów zamawianych przez redakcję czasopism przeglądowych, mogą spodziewać się wynagrodzenia finansowego. Wśród czasopism naukowych wymieniane są: czasopisma źródłowe (opisują oryginalne badania naukowe); czasopisma przeglądowe (opisują i zestawiają wnioski z publikacji źródłowych); czasopisma naukowo-techniczne (opisują badania z pogranicza nauki i przemysłu, na przykład wdrożenia wynalazków); czasopisma branżowe (zamieszczają artykuły dotyczące nowości technologicznych, naukowe artykuły przeglądowe); czasopisma popularnonaukowe (zamieszczają uproszczone artykuły przeglądowe przeznaczone dla ludzi mniej wykształconych w opisywanej dziedzinie).

Czasopisma naukowe wydawane są bądź przez wyspecjalizowane, prywatne firmy wydawnicze, bądź domy wydawnicze towarzystw naukowych lub uczelni. Obecnie dystrybucja wielu czasopism naukowych w wersji papierowej znacznie się zmniejszyła i niemal wszystkie czasopisma o ugruntowanym

\footnotetext{
${ }^{13}$ Ibidem, [dostęp: 30.05.2017].
} 
prestiżu udostępniane są przez wydawców lub w bibliotekach cyfrowych w formie plików PDF. Za pełne teksty czytelnicy muszą zapłacić, dlatego różne organizacje i biblioteki organizują udostępnianie czasopism w oparciu o licencje.

Coraz częściej utrzymanie drukarni i publikacja czasopisma naukowego $\mathrm{w}$ formie drukowanej wymaga od wydawców oferowania subskrypcji powiązanej z dostępem do artykułów przez Internet. Współcześni naukowcy wolą szukać informacji naukowej przeglądając bazy danych lub wirtualne biblioteki.

\section{Transformacja gazet codziennych, tygodników opinii i czasopism tematycznych}

Czytelnik w bibliotece, która posiada egzemplarz obowiązkowy, ma do wyboru wiele rodzajów czasopism. W przedstawionych badaniach ${ }^{14}$ dokonano analizy zainteresowań czytelniczych między innymi w zakresie takich rodzajów prasy, jak: gazety codzienne, tygodniki opinii i czasopisma tematyczne.

Sytuacja gazet codziennych wydawanych w wielkich nakładach nie jest jednoznaczna. Trendy na światowym rynku prasy wykazują, że każdego dnia ponad połowa dorosłych mieszkańców świata sięga po gazetę codzienną, z czego 2,5 miliarda wybiera wersję papierową, a zaledwie ponad 800 milionów - formy cyfrowe. Globalna sprzedaż prasy drukowanej wzrasta, ale tylko ze względu na większe zainteresowanie mieszkańców Azji (wzrost dystrybucji o 6,7\%), Ameryki Łacińskiej (6,3\%), Bliskiego Wschodu i w Afryki (wzrost $7,5 \%$ ). W krajach rozwiniętych Ameryki Północnej, Australii i Oceanii oraz Europy dystrybucja spadła nawet o $23 \%$.

Na rynku wydawniczym w krajach rozwiniętych utrzymują się wydawnictwa, które oferują treści o wysokiej jakości oraz te, które łączą wersję papierową z cyfrową. Skupienie się wyłącznie na nowej, cyfrowej rzeczywistości nie jest dochodowe. Czytelnicy przekonali się, że bezpłatne portale udostępniają wiele niesprawdzonych informacji i plotek, dlatego coraz częściej płacą za profesjonalnie zredagowane i niezależne informacje na godnych zaufania platformach. Badania wykazują, że $46 \%$ internautów wchodzi na strony internetowe gazet, ale zaledwie $6 \%$ czyta zawarte tam treści. Za bardziej wiarygodne uważane są treści, za które trzeba zapłacić.

Wydawcy śledzą te tendencje i starają się zaspokoić nowe oczekiwania czytelników. W 2015 r. wydawcy New York Times Co. i Axel Springer zakupili cyfrową platformę, która umożliwia przeglądanie i czytanie artykułów

\footnotetext{
${ }^{14}$ Ibidem, [dostęp: 30.05.2017].
} 
w modelu PPV (pay per view). Tendencja pobierania płatności za pojedyncze artykuły prasowe rozprzestrzenia się wśród dużych wydawców gazet. Od 2012 do 2013 r. przychody ze sprzedaży treści w Internecie wzrosły o 60\%, a w ciągu pięciu lat wskaźnik ten wzrósł o $2000 \%$ (od punktu prawie zerowego). Wydawcy nie boją się ekspansji cyfrowej rzeczywistości i starają się zwiększyć zaangażowanie odbiorców na platformach cyfrowych, a także przyciągają czytelników doskonaląc nawigację na swoich stronach internetowych. Coraz częściej tytuły poczytniejszych gazet są obecne w mediach społecznościowych, gdzie promowane są nowe wydania. Według raportu World Press Trends (WPT) z 2014 r., wydanego przez Światowe Stowarzyszenie Prasy i Wydawców Wiadomości (WAN-IFRA), nastąpiło połączenie sił prasy drukowanej i cyfrowej, co przyczyniło się do globalnego zwiększenia jej sprzedaży ${ }^{15}$.

Diagnoza społecznych zachowań czytelniczych prasy drukowanej i cyfrowej przedstawiona $\mathrm{w}$ raporcie $\mathrm{z}$ badania zrealizowanego na zlecenie Izby Wydawców Prasy potwierdza stopniowe przesunięcie zainteresowań czytelniczych w kierunku prasy cyfrowej ${ }^{16}$. Analiza czytelnictwa gazet codziennych dokonana w oparciu o badania Izby Wydawców Prasy została przedstawiona na rys. 4.

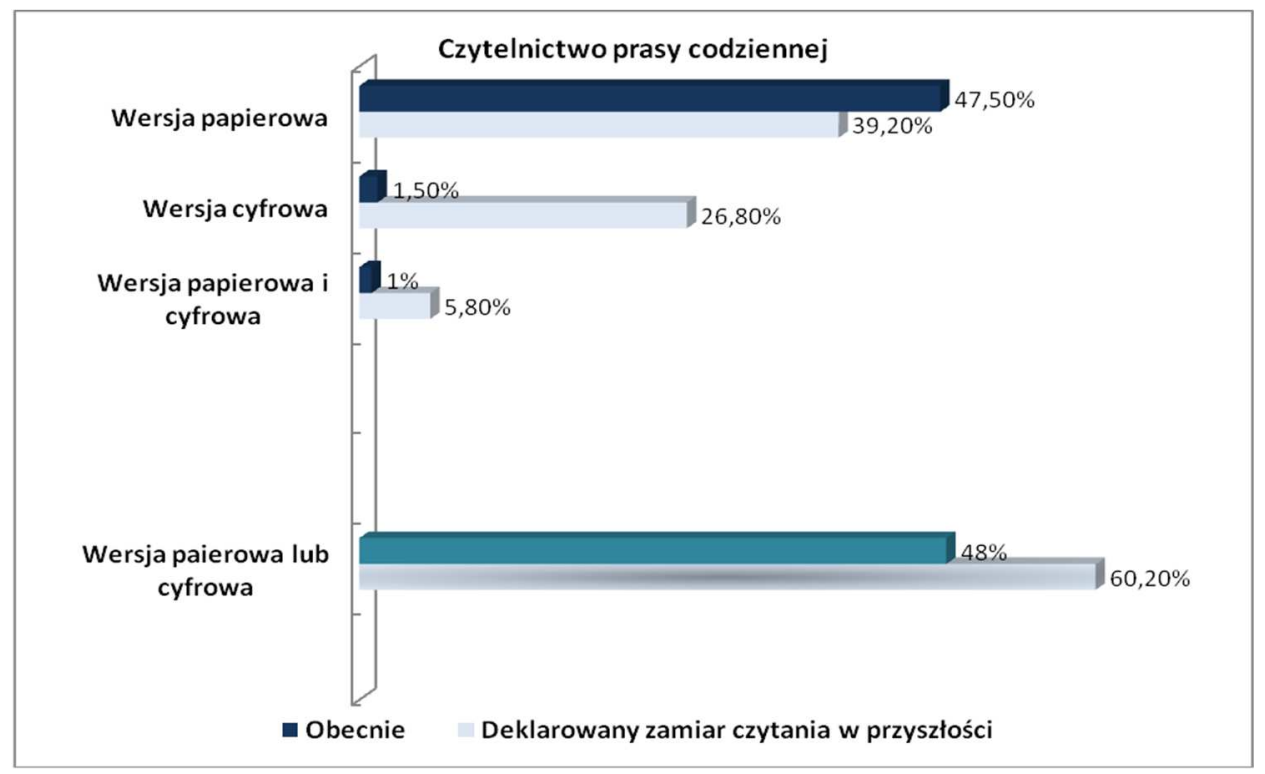

Rys. 4. Czytelnictwo gazet codziennych w wersji papierowej i cyfrowej uczestników badania Izby Wydawców Prasy czych...

Źródło: opracowanie własne na podstawie Diagnoza społecznych zachowań czytelni-

${ }^{15}$ Trendy na światowym rynku prasy, http://www.print-partner.com.pl/print_pub/publik/ 2015/trendy-na-swiatowym-rynku-prasy.html, [dostęp: 30.05.2017].

${ }^{16}$ Diagnoza społecznych zachowań czytelniczych..., [dostęp: 30.05.2017]. 
$\mathrm{Z}$ deklaracji osób uczestniczących $\mathrm{w}$ badaniu wynika, że zamierzają zwiększyć zakres czytelnictwa gazet codziennych w wersji cyfrowej z 1,5\% do $26,8 \%$, czyli o $25,3 \%$. Zmniejszy się natomiast czytelnictwo gazet w wersji papierowej z 47,5\% do 39,2\%, czyli o 8,3\%. Ogólnie deklarowane czytelnictwo gazet codziennych, dzięki wersji elektronicznej, powinno wzrosnąć z 48\% do $60,2 \%$, to jest o $12,2 \%$.

Rynek wydawniczy czasopism opiniotwórczych jest bardzo stabilny. Jedynie niektórzy czytelnicy zamiast 2-3 tygodników kupują jeden tytuł. $\mathrm{Na}$ rys. 5 przedstawiono czytelnictwo tygodników opinii w wersji papierowej i cyfrowej przedstawione $\mathrm{w}$ raporcie $\mathrm{z}$ badania zrealizowanego na zlecenie Izby Wydawców Prasy.

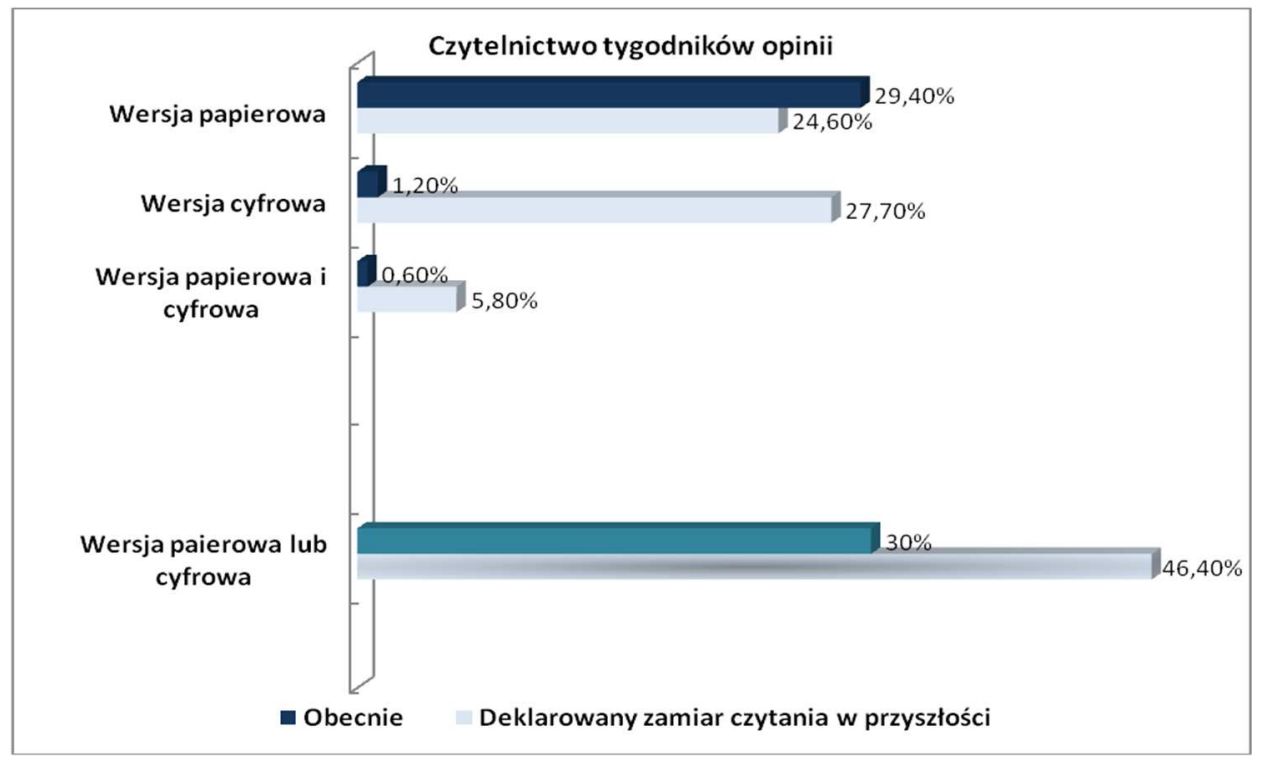

Rys. 5. Czytelnictwo tygodników opinii w wersji papierowej i cyfrowej

Źródło: opracowanie własne na podstawie Diagnoza społecznych zachowań czytelniczych...

Respondenci, uczestniczący w badaniu deklarowali wzrost czytelnictwa tygodników opinii w wersji cyfrowej z $1,2 \%$ do $27,7 \%$, czyli o $26,5 \%$. Zainteresowanie tygodnikami opinii $\mathrm{w}$ wersji online jest więc nieco wyższe niż zainteresowanie gazetą codzienną $\mathrm{w}$ wersji cyfrowej. Natomiast spadek czytelnictwa tygodników opinii w wersji papierowej z $29,4 \%$ do $24,8 \%$, czyli o $4,6 \%$ jest znacznie mniejszy, niż w przypadku gazet codziennych.

Czasopisma specjalistyczne, tematyczne, wydawane są w małych nakładach, ale posiadają wierną grupę czytelników, którzy gwarantują im stabilność na rynku. Na rys. 6 przedstawiono dane dotyczące czytelnictwa czasopism tematycznych w wersji papierowej i cyfrowej. 


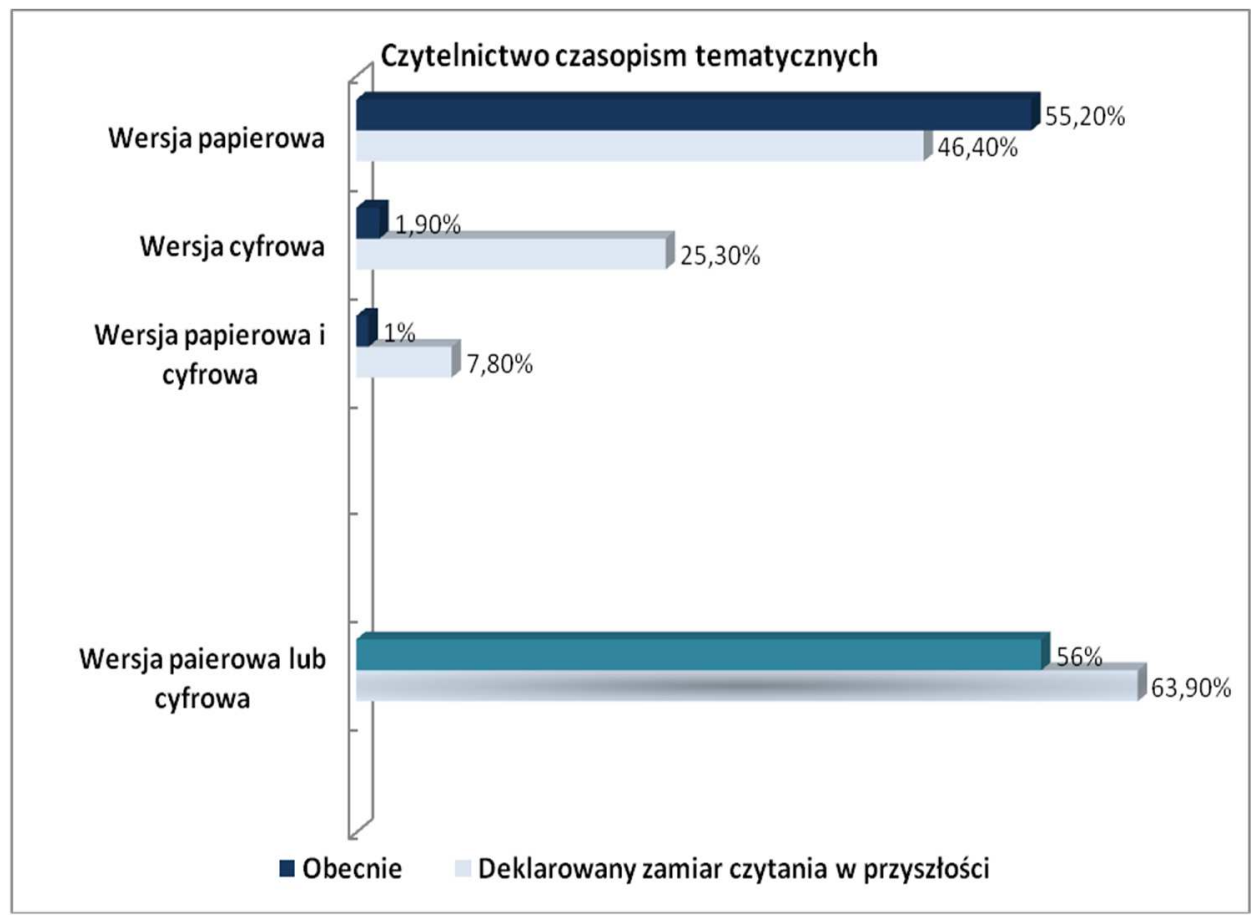

Rys. 6. Czytelnictwo czasopism tematycznych w wersji papierowej i cyfrowe uczestników badania Izby Wydawców Prasy czych...

Źródło: opracowanie własne na podstawie Diagnoza społecznych zachowań czytelni-

W przypadku czasopism tematycznych uczestnicy badania również zadeklarowali znaczny wzrost czytelnictwa czasopism w wersji cyfrowej, z 1,9\% do $25,3 \%$, czyli o 23,4\%. Czytelnictwo czasopism tematycznych w wersji papierowej miałoby spaść z $55,2 \%$ do $46,4 \%$, czyli o $8,8 \%$. Ogólny wzrost czytelnictwa czasopism tematycznych, dzięki wersji elektronicznej, powinien zwiększyć się z $56 \%$ do $63,9 \%$, czyli o $7,9 \%$.

Transformacja prasy na nośniki cyfrowe będzie prawdopodobnie najkorzystniejsza dla tygodników opinii, gdyż prognozowany wzrost zainteresowania czytaniem formy cyfrowej był największy. Blisko połowa czytelników $(46,8 \%)$ nie kojarzy prasy cyfrowej z wersją drukowaną i postrzega ją jako nową i atrakcyjną formę przekazu informacji, po którą mają zamiar sięgać coraz częściej. Uważają również, że wiele tytułów może zyskać na popularności dzięki wersji cyfrowej. Przeprowadzone badania wykazały wzrost czytelnictwa w każdym z analizowanych rodzajów prasy, wynikający z pojawienia się wersji elektronicznej periodyków. Ten pozytywny trend świadczy również o tym, że znaczenie prasy nie zmaleje, a powinno wzrastać.

Uczestników badania poproszono o wyrażenie ich opinii odnośnie prasy papierowej. Uzyskane dane przedstawiono na rys. 7. 


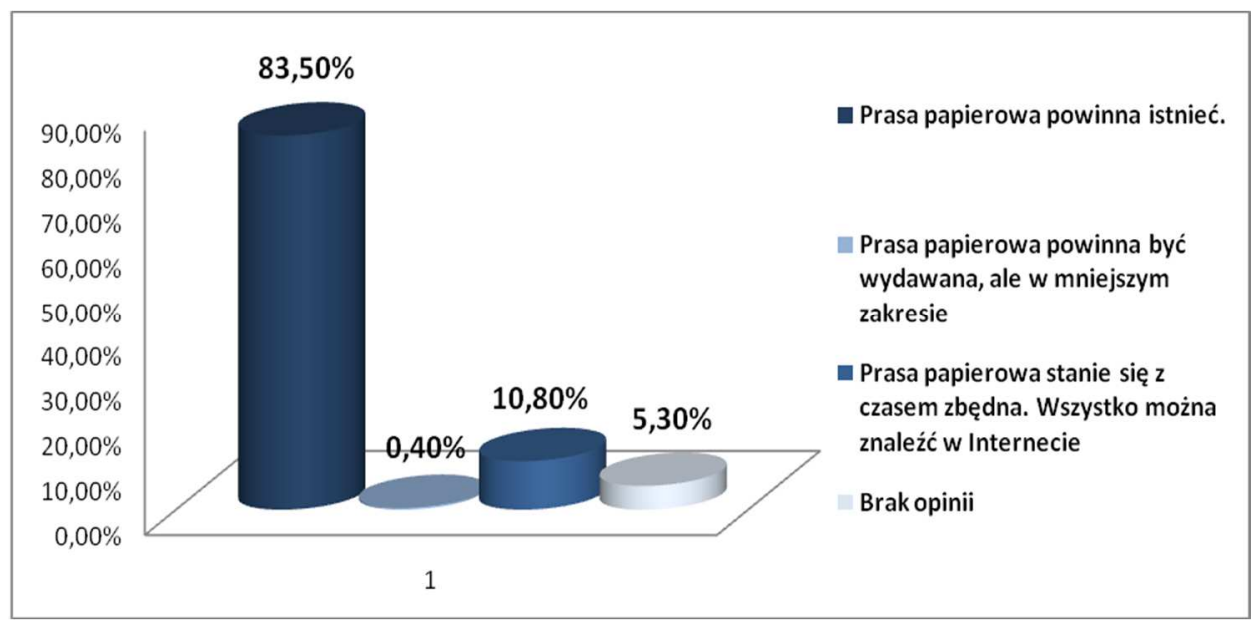

Rys. 7. Oczekiwania czytelników uczestniczących w badaniu Izby Wydawców Prasy dotyczące prasy papierowej czych...

Źródło: opracowanie własne na podstawie Diagnoza społecznych zachowań czytelni-

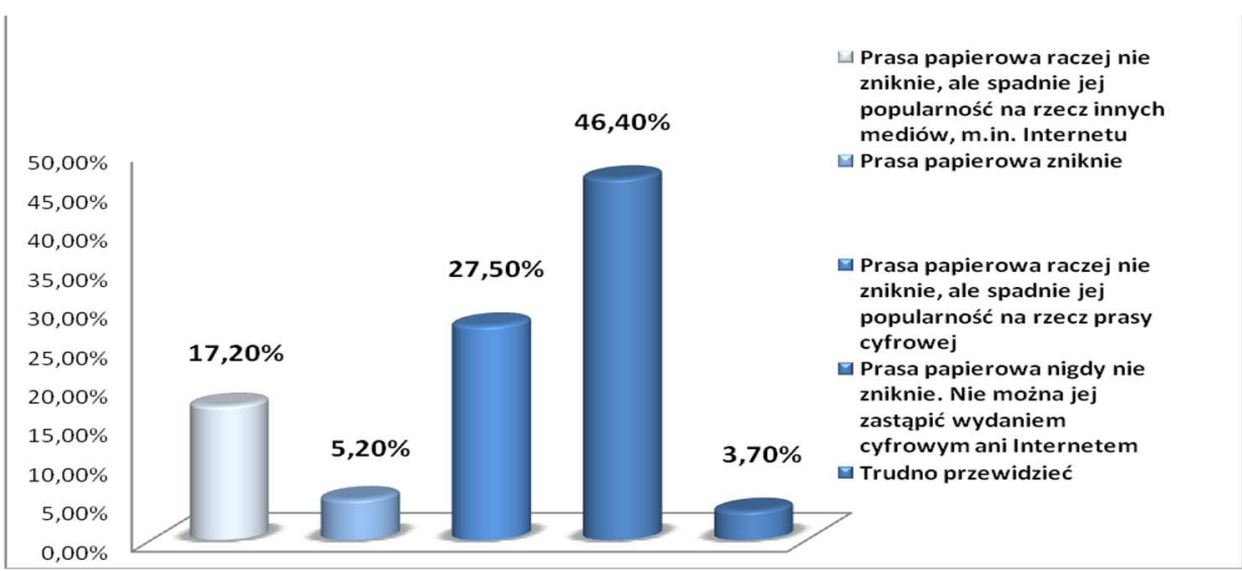

Rys 8. Prognozy uczestników badania Izby Wydawców Prasy dotyczące przyszłości prasy papierowej czych...

Źródło: opracowanie własne na podstawie Diagnoza społecznych zachowań czytelni-

Czytelnicy uczestniczący w badaniu w zdecydowanej większości (83,5\%) byli przekonani, że prasa papierowa powinna istnieć. W opinii $0,40 \%$ badanych prasa papierowa powinna być wydawana, ale w mniejszym zakresie. Kolejnych 10,8\% uważało, że prasa papierowa stanie się z czasem zbędna, a 5,3\%, że nie będzie potrzebna, że wszystko można znaleźć w Internecie.

Uczestników badania poproszono o ich przewidywania dotyczące przyszłości prasy papierowej. Zebrane dane przedstawiono na rys. 8 . 
Prognozy czytelników dotyczące istnienia prasy papierowej były raczej optymistyczne, chociaż wszyscy przewidywali spadek popularności na rzecz Internetu i prasy cyfrowej. Większość (46,40\%) respondentów uważała, że prasa papierowa nigdy nie zniknie, gdyż nie można jej zastąpić wydaniem cyfrowym ani Internetem. Kolejnych $27,5 \%$ prognozowało, że prasa papierowa raczej nie zniknie, ale spadnie jej popularność na rzecz prasy cyfrowej. Grupa $17,20 \%$ badanych wyraziła opinię, że prasa papierowa raczej nie zniknie, ale spadnie jej popularność na rzecz innych mediów, między innymi Internetu. Ponad 5\% ankietowanych przewidywało, że prasa papierowa zniknie.

Autorzy badań wysunęli kilka zasadniczych wniosków. Przede wszystkim zauważali, że prasa powinna transmitować swoją tożsamość na nową platformę, zastępującą tradycyjny papier, ponieważ nie maleje znaczenie prasy. Prasa w dalszym ciągu kształtuje i rozwija zainteresowania, stanowi najbardziej wartościowy zasób treści, cieszy się uznaniem i poważaniem oraz znacznie wyższym autorytetem niż media dostarczające bezpłatnych treści. Odbiorcy nie zastępują prasy papierowej cyfrową. Obie wersje mogą harmonijnie koegzystować ze sobą. Prasa papierowa traktowana jest jako zasób informacji lokalnych, rozrywki, czy artykułów hobbystycznych, natomiast prasa cyfrowa jest źródłem dłuższych i bardziej złożonych tekstów.

\section{Perspektywy dla bibliotek wynikające $\mathrm{z}$ transformacji prasy}

Celem bibliotek jest przetrwanie i rozwój. Przez wieki funkcje bibliotek (gromadzenie, opracowanie, udostępnianie) nie zmieniały się, gdyż to papier był podstawowym nośnikiem informacji. W ciągu pierwszych lat komputeryzacji bibliotek budynki, magazyny, czytelnie i strony internetowe stanowiły jeden organizm, ponieważ tradycyjna papierowa książka i czasopismo wciąż była czytelnikom niezbędna. Jednak w krótkim odstępie czasu Internet jako super-biblioteka stał się wielkim konkurentem bibliotek. Dokumenty elektroniczne nie potrzebują magazynu, są przechowywane na dysku komputerowym. W tej sytuacji zminimalizowane zostały dwie tradycyjne funkcje biblioteki: gromadzenie i przechowywanie. Cyfrowe gromadzenie i przechowywanie zmieniło oblicze tradycyjnej biblioteki ${ }^{17}$. Wewnętrzne procesy biblioteczne podporządkowane zostały udostępnianiu i informacji, w tym także o zbiorach innych bibliotek.

\footnotetext{
${ }^{17}$ R. Gaziński, Zmienna czy trwała natura biblioteki naukowej? [w:] Biblioteki naukowe $w$ kulturze i cywilizacji. Materiaty konferencyjne Poznań, 15-17 czerwca 2005, red. H. Ganińska, Poznań 2005.
} 
Transformacja prasy z formy papierowej na cyfrową może sprawić, że bez formy drukowanej tradycyjne funkcje bibliotek zanikną, co całkowicie przeobrazi lub zlikwiduje znany system biblioteczny. Myśli ludzkie zapisane na papierze będą przechowywane w bibliotekach historycznych - archiwach, które przejmą funkcje dzisiejszych bibliotek i odwiedzane będą tylko przez badaczy dawnych czasów. Wrócimy do czasów starożytnych, kiedy to materiały biblioteczne były jedynie źródłem wiedzy o przeszłości.

Można przewidzieć również inną, bardziej optymistyczną przyszłość bibliotek, jeśli nastąpi ich globalizacja i związany z tym ułatwiony dostęp do informacji. Dostęp do informacji w bibliotekach powinien być oparty na:

- odpowiedniej polityce gromadzenia i udostępniania zbiorów cyfrowych;

- $\quad$ współpracy z innymi bibliotekami;

- wyrównywaniu szans czytania potrzebnych materiałów, poprzez zwiększenie dostępu w ramach konsorcjów, wymiany międzybibliotecznej i licencji wersji cyfrowej;

- $\quad$ posiadanie i udostępnianie sieci Internet, wraz z dostępem do prenumeraty prasy i do pojedynczych artykułów w wersji cyfrowej.

Zatem biblioteka powinna stać się instytucją wielosemiotyczną (multijęzykową), pośredniczącą w różnych formach komunikacji i gwarantującą dostęp online.

\section{Podsumowanie}

Prasa nie jest podstawowym źródłem wiedzy i informacji, jednak Diagnoza społecznych zachowań czytelniczych $w$ obrębie prasy drukowanej i cyfrowej przedstawiona $\mathrm{w}$ raporcie $\mathrm{z}$ badania zrealizowanego na zlecenie Izby Wydawców Prasy opracowanego przez Millward Brown ${ }^{18}$ wykazała, że dla większości czytelników prasa stanowi najbardziej wartościowy zasób treści. W wizerunku prasy dostrzegali oni takie cechy jak profesjonalizm, uczciwość, autorytet, wiarygodność i inteligencja.

Dla wielu czytelników atrakcyjniejszą formą przekazu treści staje się wersja cyfrowa prasy. Pracownicy bibliotek dostrzegają chmury nad bibliotekami, dlatego optymizm wzbudza raport z badań, który prognozuje wzrost zainteresowania czytelnictwem prasy, ze względu na większą dostępność formy cyfrowej tygodników opiniotwórczych, czasopism tematycznych oraz gazet codziennych. Diagnoza zachowań czytelniczych $\mathrm{w}$ zakresie prasy nie przedstawia korzystnej wizji dla udostępniania prasy papierowej w bibliotekach. Jednak

\footnotetext{
${ }^{18}$ Diagnoza społecznych zachowań czytelniczych...
} 
spostrzeżenia analityków rynku wydawniczego w zakresie rosnącego znaczenia informacji zawartych w prasie, dają nadzieję, że jeszcze wiele lat wersja drukowana będzie stanowiła źródło wiedzy i opinii społecznej, ze względu na tendencje do poszukiwania zupełnie innych treści niż w wersji cyfrowej. Biblioteki mają również możliwość wyjścia $\mathrm{z}$ ofertą udostępniania wersji cyfrowej prasy cieszącej się większym zainteresowaniem czytelników.

Obserwowany spadek przychodów z wydań papierowych spowodowany dostępem do bezpłatnych informacji w Internecie częściowo uległ zatrzymaniu. Niektórzy czytelnicy zawiedli się na szybkim rozpowszechnianiu przez portale informacyjne niesprawdzonych wiadomości. Dlatego ważne jest, aby w coraz większym zakresie mieli oni dostęp do profesjonalnych treści prasowych i aby kulturotwórcza rola prasy nie została zniszczona przez zmiany cywilizacyjne. $\mathrm{W}$ dobie transformacji prasy funkcja bibliotek w tym zakresie nie powinna maleć. Czytelnicy nieustannie poszukują informacji i kształcą się, korzystając ze wszystkich dostępnych źródeł, to na tę chwilę byt bibliotek wydaje się nie być zagrożony. Jednak trudno nie oprzeć się wrażeniu, że biblioteki, a szczególnie czytelnie udostępniające czasopisma, nabierają elitarnego charakteru, a rolą bibliotekarzy staje się udostępniane zbiorów archiwalnych, unikatowych, również na nośnikach cyfrowych.

\section{Bibliografia}

Diagnoza spolecznych zachowań czytelniczych w obrębie prasy drukowanej i cyfrowej. Nowe platformy dostęu do treści. Transformacja prasy. Raport z badania zrealizowanego na zlecenie Izby Wydawców Prasy opracowany przez Millward Brown, http://www.pik.org.pl/upload/files/Raport\%20RYNEK\%2011-02-2014\% 20\%28R\%29\%20word\%20IWP-1.pdf, [dostęp: 30.05.2017].

Gaziński R., Zmienna czy trwała natura biblioteki naukowej?, [w:] Biblioteki naukowe $w$ kulturze i cywilizacji: działania i codzienność. Materialy konferencyjne Poznań, 15-17 czerwca 2005, red. H. Ganińska, Poznań 2005, s. 2-12.

Jędrzejewski S., Media a zmiana spoleczna, [w:] Kultura, media, społeczeństwo, red.

D. Wadowski, Lublin 2007, s. 263-274.

Stownik terminologii medialnej, red. W. Pisarek, Kraków 2006.

Taczkowska J., Zawód dziennikarza w Polsce. Między misja a postannictwem, Bydgoszcz 2012.

Trendy na światowym rynku prasy, http://www.print-partner.com.pl/print_pub/publik/ 2015/trendy-na-swiatowym-rynku-prasy.html, [dostęp: 30.05.2017].

Prawo prasowe. Ustawa z dnia 26 stycznia 1984 r., „Dziennik Ustaw” 1984, nr 5, poz. 24.

Ziarek P.P., Kultura popularna a nowe media, [w:] Konteksty kultury popularnej: pteć, sztuka, media, red. M. Jeziński [et al.], Toruń 2010, s. 193-205. 